\title{
Telomere length shortening associated with cataract in younger adults
}

\section{Acortamiento de la longitud telomérica en adultos jóvenes con catarata}

\author{
Vanesa Rivero-Gutiérrez ${ }^{1,2 *}$, Javier Fernández-Mateos ${ }^{2,3}$, Lourdes de Juan-Marcos ${ }^{1,2}$, Fernando Cruz-González ${ }^{1,2}$, \\ Emiliano Hernández-Galilea1,2, and Rogelio González-Sarmiento ${ }^{2,3,4}$ \\ ${ }^{1}$ Department of Ophthalmology, University Hospital of Salamanca; ${ }^{2}$ Institute of Biomedical Research of Salamanca (IBSAL), University Hospital of \\ Salamanca, Consejo Superior de Investigaciones Científicas (CSIC); ${ }^{3}$ Molecular Medicine Unit, Department of Medicine, University of Salamanca; \\ ${ }^{4}$ Institute of Molecular and Cellular Biology of Cancer (IBMCC), University of Salamanca, CSIC. Salamanca, Spain
}

\begin{abstract}
Purpose: A prospective observational study was performed that included 205 adults, 102 cases and 103 controls, classified into the age groups of $\leq 55$ and $\geq 60$ years old, to examine the prognostic value of telomere length in patients with or without cataract and to assess the effects of telomerase ribonucleic acid (RNA) gene variants (telomerase reverse transcriptase [TERC] and telomere RNA component [TERT]) on telomere length. Methods: Telomere length and telomerase polymorphisms were quantified in peripheral blood leukocytes by a quantitative polymerase chain reaction. TaqMan ${ }^{\circledR}$ probes were used for telomerase polymorphisms (TERT 1327C > T and TERC 63G > A) genotyping. Results: Regardless of age, patients with cataracts had shorter telomere lengths compared to healthy controls $(p<0.01)$. No association was detected between telomere shortening and TERC 63G > A in both cases and controls, and no correlation was observed between leukocyte telomere length and cardiovascular risk factors in patients with cataracts. Conclusions: Irrespective of age, telomeres in peripheral blood leukocytes of patients with cataracts were shorter compared to subjects without cataracts. Our findings suggest that the development of cataract is associated with peripheral blood cell aging.
\end{abstract}

Key words: Cataract. Diabetes. Hypertension. Telomere length. Polymorphism. Smoking.

\section{Resumen}

Objetivo: Se realizó un estudio prospectivo observacional con 205 adultos (102 casos y 103 controles) clasificados en grupos de $\leq 55$ años $y \geq 60$ años, con el fin de evaluar la longitud telomérica en pacientes con y sin catarata, y los efectos de los polimorfismos (TERC y TERT) de la telomerasa sobre dicha longitud. Métodos: La longitud telomérica y los polimorfismos de la telomerasa se cuantificaron en leucocitos de sangre periférica por reacción en cadena de la polimerasa. Se utilizaron sondas TaqMan $^{\circledR}$ para genotipificar polimorfismos de telomerasa (TERT 1327C>T y TERC 63G>A). Resultados: Independientemente de la edad, los pacientes con catarata tenían longitudes teloméricas más cortas que los controles $(p<0.01)$. No se detectó asociación entre el acortamiento de los telómeros y TERC 63G>A en casos ni en controles, y no hubo correlación entre la longitud telomérica en los leucocitos y los factores de riesgo cardiovascular en los pacientes con catarata. Conclusiones: Sin que influyera la edad, los telómeros en leucocitos de sangre periférica de pa-

Correspondence:

*Vanesa Rivero Gutiérrez

Gran Vía del Este, 80

Date of reception: 05-03-2020

Date of acceptance: 30-06-2020

E-mail: v.rivero.g@ hotmail.com

DOI: 10.24875/RMOE.M20000136
Available online: 11-01-2021 Rev Mex Oftalmol (Eng). 2021;95(1):1-7 www.rmo.com.mx 2604-1731/@ 2020 Sociedad Mexicana de Oftalmología. Published by Permanyer. This is an open access article under the CC BY-NC-ND license (http://creativecommons.org/licenses/by-nc-nd/4.0/). 
cientes con catarata fueron más cortos que en aquellos sin catarata. Nuestros hallazgos sugieren que el desarrollo de cataratas está asociado con el envejecimiento de las células de la sangre periférica.

Palabras clave: Cataratas. Diabetes. Hipertensión. Longitud telomérica. Polimorfismo. Tabaquismo.

\section{Introduction}

Telomeres are nucleotide repeat sequences that cap the ends of chromosomes. With each cell division, telomeres shorten until they reach a critical length when the cell can no longer replicate, causing senescence or death. This mechanism leads to a decline in cell function. It has been suggested that short telomeres could be markers of low resistance to stress ${ }^{1}$. Accordingly, telomere length has been proposed as an indicator of cell aging and longevity and has been associated with many diseases related to aging and lifespan ${ }^{2,3}$.

To maintain telomere length, the enzyme telomerase is responsible for synthesizing GGTTAG repeats at the ends of chromosomes. Human telomerase mainly consists of telomerase reverse transcriptase (telomere ribonucleic acid component [TERT]), telomerase ribonucleic acid (RNA) (telomerase reverse transcriptase [TERC]), and dyskerin (DKC1). Common genetic variants, TERT 1327C > T rs27350940 and TERC 63G $>$ A rs2293607, have been recently linked to reduced telomerase activity, causing premature telomere shortening ${ }^{4,5}$. These genes are expressed in embryonic tissues orperipheral mononuclear cells but have not been identified in the human lens.

Further, telomere length has been associated with cardiovascular risk factors such as diabetes, high blood pressure, and smoking ${ }^{6}$. In fact, patients with diabetes have shorter telomeres than healthy individual ${ }^{7}$, and individuals with short telomere lengths show more diabetic complications $^{8}$. In addition, several studies have detected a faster telomere shortening in smokers, probably due to oxidative damage caused by tobacc $0^{9}$. In the Framingham Heart Study, hypertensive men were found to have significantly shorter age-adjusted leukocyte telomere lengths compared to their normotensive peers ${ }^{10}$. However, this association could not be confirmed in a mixed male and female cohort examined in the Cardiovascular Health Study ${ }^{11}$. Thus, there could bea sex-related effect on leukocyte telomere length in humans, whereby telomere length is shorter in adult men compared to women ${ }^{12}$.

The hypothesis that lens transparency could be related to leukocyte telomere length as a marker of aging is supported by observations in premature aging disorders such as Werner syndrome. In patients with this syndrome, features linked to normal aging, including cancer and bilateral cataracts, appear early, and patients show accelerated telomere shortening ${ }^{13-15}$.

This study was designed to examine leukocyte telomere length in younger adults with cataract and assess the supposed association between TERT and TERC gene polymorphisms and premature cataracts. We also determined whether telomere length differed between subjects with and without cardiovascular risk factors to eliminate confounding factors (smoking, diabetes, and hypertension), possibly causing telomere shortening.

\section{Patients and methods}

\section{Subjects}

Blood samples were collected from 205 subjects after obtaining their informed consent. The study protocol received Institutional Review Board approval and adhered to the principles of the Declaration of Helsinki. Subjects were divided into four groups: 46 subjects with cataract aged $\leq 55$ years matched with 47 subjects without cataracts of similar age, and 56 subjects with cataract aged $\geq 60$ years matched with 56 subjects without cataract of similar age. Clinical and demographic characteristics are summarized in table 1 (clinical and demographic characteristics of the subjects included in our study). Mean age of the subjects in the four groups was $48.5 \pm 7.47$ years (cataract $\leq 55$ ), $43.8 \pm 7.63$ (cataract-free $\leq 55$ years), $72.5 \pm 7.6$ years (cataract $\geq 60$ years), and $66.5 \pm 4.3$ years (cataract-free $\geq 60$ years).

All participants underwent a standard ophthalmologic examination, including best-corrected visual acuity (BCVA), refraction, intraocular pressure measurement, and ultrasound biometry. The examination included observation of the dilated anterior segment using a slit lamp to verify the presence or absence of cataract (nuclear, cortical, and posterior subcapsular) and ocular fundus evaluation. Lens transparency was graded according to the validated Lens Opacities Classification System (LOCS) III.

Inclusion criteria for patients were BCVA $<0.5$ Snellen decimal after excluding any other ophthalmological pathology that could explain the loss of visual acuity and the presence of cataract confirmed by ocular examination. For controls, inclusion criteria were BCVA = 1 in the absence of cataracts according to the LOCS 
Table 1. Clinical and demographic characteristics of the subjects included in our study

\begin{tabular}{|l|c|c|c|c|}
\hline & Cases $\leq 55$ years, $n \%$ & Controls $\leq 55$ years, $n \%$ & Cases $\geq 60$ years, $n \%$ & Controls $\geq 60$ years, $n \%$ \\
\hline Sample size & 46 & 47 & 56 & 56 \\
\hline $\begin{array}{l}\text { Gender } \\
\text { Men } \\
\text { Women }\end{array}$ & $28(60.9)$ & & & $18(32.1)$ \\
\hline Hypertension & $18(39.1)$ & $21(44.7)$ & $25(44.6)$ & $38(67.9)$ \\
\hline Diabetes & $9(19.6)$ & $26(55.3)$ & $31(55.4)$ & $30(53.6)$ \\
\hline Smoking & $10(21.7)$ & $4(8.5)$ & $32(57.1)$ & $13(23.2)$ \\
\hline
\end{tabular}

III. All subjects, cases and controls, met the same criteria in terms of place of residence or out/indoor job (to control environmental risks such as sun exposure).

Exclusion criteria were present or past treatment-related to the development of cataract (corticosteroids, vitreoretinal surgery, chemotherapy, and radiation), alcohol abuse, and any local (eye trauma, uveitis, and glaucoma) or systemic disease associated with cataract (Steinert disease, metabolic disorders, Marfan syndrome, and other skeletal muscle diseases).

\section{DNA extraction}

Genomic DNA was extracted from nucleated peripheral blood cells following the phenol-chloroform method, as previously reported ${ }^{16}$.

\section{Telomere length analysis}

Telomere length was measured by relative and comparative quantitative polymerase chain reaction (PCR). We compared mean telomere repeat sequence copy number with the reference single copy gene 36B4. For the each DNA sample, we performed six different experiments: 3 (for telomere repeat sequence) and 3 (for single-copy gene). The method was described by Gil and Coetzer in $2004^{17}$ using the same primers developed by Cawthon in 2002 for telomere length ${ }^{18}$ and the $36 \mathrm{~B} 4$ gene as endogenous control ${ }^{19}$. The telomere-specific primers were forward, 5'-GGTTTTTGAGGGTGAGGGTGAGGGTGA GGG TGAGGGT-3' and reverse, 5'-TCCCGACTATCCCTATCCCTATCCCTATCCC TATCCCTA-3'. The 36b4-specific primers were forward, 5'-CAGCAAGTGGGAAGG TGTAATCC-3' and reverse, 5'-CCC ATTCTATCATCAACGGGTACAA-3'20. The control gene 36B4 was amplified under the same PCR conditions as the telomere gene, thus reducing the risk of inter-plate variation.
The following was added to each well: $5 \mathrm{ng} / \mu \mathrm{L}$ of DNA, $5 \mathrm{~mL}$ of SYBR Green PCR Master Mix (Kapa Biosystems) and $4 \mathrm{~mL}$ of $\mathrm{H}_{2} \mathrm{O}$. We also added $1 \mu \mathrm{L}$ of "forward" primer $(5 \mu \mathrm{M})$ and $2.33 \mu \mathrm{L}$ of "reverse" primer $(5 \mu \mathrm{M})$ for the telomere amplification reaction, and $0.4 \mu \mathrm{L}(5 \mu \mathrm{M})$ of each primer for the amplification of the 36B4 gene. The thermal cycling profile proceeded as follows: $10 \mathrm{~min}$ at $95^{\circ} \mathrm{C}$ followed by 35 cycles of $95^{\circ} \mathrm{C}$ for $15 \mathrm{~s}, 54^{\circ} \mathrm{C}$ for $2 \mathrm{~min}$, and $72^{\circ} \mathrm{C}$ for $15 \mathrm{~s}^{21}$. qPCR amplification was performed using the Step-One Plus Real-time PCR system (Applied Biosystems). The RQ Manager Software version 1.2 was used to determine relative telomere length.

The $\mathrm{Ct}$ value, defined as the number of PCR cycles needed for the amplified DNA to cross a predefined threshold, was used to calculate the telomere repeat copy number to single-copy gene copy number ratio (T/S) using T/S = 22DCt. The relative telomere length was determined by normalizing the ratio (T/S) of each sample to the calibrator DNA to standardize sample values across all reaction plates. For ease of data manipulation, the natural log of this value was used ${ }^{22}$.

\section{Telomerase polymorphism analysis}

Telomerase gene DNA polymorphisms were measured using a real-time PCR allelic discrimination procedure conducted in a total volume of $12 \mu \mathrm{L}$ per reaction. DNA $(2.5 \mu \mathrm{L})$ was placed in a $9.5 \mu \mathrm{L}$ reaction mixture containing $0.25 \mu \mathrm{L}$ of oligonucleotide primers and TaqMan probes (VIC/FAM), $5 \mu \mathrm{L}$ of TaqMan ${ }^{\circledR}$ Universal PCR Master Mix No AmpErase ${ }^{\circledR}$ UNG (Applied Biosystems), and made up with double-distilled $\mathrm{H}_{2} \mathrm{O}$ to a final volume of $12 \mu \mathrm{L}$. Following the manufacturer's instructions for the Step-One Plus Real-time PCR system (Applied Biosystems), the cycling protocol consisted of an initial $10-$ min denaturation step at $95^{\circ} \mathrm{C}$, followed by 
Table 2. Sequences of VIC and FAM probes $\left(5^{\prime}-3^{\prime}\right)$ used for TERT-1327C $>$ T and TERC-63G > A polymorphism detection by real-time PCR

\begin{tabular}{|c|c|c|}
\hline Polymorphism & $\begin{array}{l}\text { TaqMan Probe (Applied } \\
\text { Biosystems) }\end{array}$ & Sequence 5'-3' (VIC/FAM) \\
\hline TERT-1327C > T (rs2735340) & C_1839086_10 & TCGTCTTGTAAATACTTAGGATTAC(A/G)GGTCGCTCTTCTAGAAATCCCCTTA \\
\hline TERC-63G > A (rs2293607) & C_16184740_10 & AGGTTTGGGGGTTCACAAGCCCCCA(C/T)TGCCGGCGAGGGGTGACGGATGCGC \\
\hline
\end{tabular}

40 cycles of denaturation at $95^{\circ} \mathrm{C}$ for $15 \mathrm{~s}$, annealing at $65^{\circ} \mathrm{C}$ for $60 \mathrm{~s}$, and an extension stage at $60^{\circ} \mathrm{C}$ for $30 \mathrm{~s}$.

The sequences of VIC and FAM probes used for polymorphism detection are detailed in table 2 .

\section{Statistical analysis}

Statistical analysis was performed using SPSS Statistics for Windows software, version 2.0 and the GenEx 5.3.6 program developed to calculate telomere length. To confirm the GenEx software results, we used a Mann-Whitney U test.

Associations between leukocyte telomere length and TERT/TERC polymorphisms (single nucleotide polymorphisms [SNPs]) were modeled using a Chi-square test.

As some data followed a normal distribution and others (age) showed a non-parametric distribution, analysis of variance (ANOVA) or the Mann-Whitney $U$ test was used to examine the influence of possible confounding variables (diabetes, smoking, hypertension, and age) on telomere length in patients with cataracts. We also performed a multivariate ANOVA (MANOVA) to compare these dependent variables together (diabetes, smoking, hypertension, and age) in the same groups.

\section{Results}

Significant differences were observed in relative telomere length between subjects with cataracts and those without cataract regardless of age $(p<0.01)$. As expected, according to the impact of age on telomere length, subjects without cataract aged 60 years or older had shorter telomeres than those 60 years or under $(p<0.01)$. However, we found significant differences $(p<0.01)$ in telomere length in subjects with cataract unrelated to age. Interestingly, the younger subjects with cataract had shorter telomeres than older individuals with cataract (Table 3: leukocyte telomere lengths compared between study groups).
Table 3. Leukocyte telomere lengths compared between study groups

\begin{tabular}{|l|c|c|}
\hline & Telomere length & P-value \\
\hline $\begin{array}{l}\text { Cases vs. } \\
\text { Controls }\end{array}$ & $2.88 \pm 1.43$ & $\mathrm{P}<0.01$ \\
\hline $\begin{array}{l}\text { Cases } \leq 55 \text { years vs. } \\
\text { Controls } \leq 55 \text { years }\end{array}$ & $2.36 \pm 1.56$ & $\mathrm{P}<0.01$ \\
\hline $\begin{array}{l}\text { Cases } \geq 60 \text { years vs. } \\
\text { Controls } \geq 60 \text { years }\end{array}$ & $3.85 \pm 1.58$ & \\
\hline $\begin{array}{l}\text { Cases } \leq 55 \text { years vs. } \\
\text { Cases } \geq 60 \text { years }\end{array}$ & $4.69 \pm 1.30$ & $\mathrm{P}<0.01$ \\
\hline $\begin{array}{l}\text { Controls } \leq 55 \text { years vs. } \\
\text { Controls } \geq 60 \text { years }\end{array}$ & $2.36 \pm 1.56$ & $\mathrm{P}<0.01$ \\
\hline
\end{tabular}

The hypothesis that inter-individual variations in TERT and TERC telomerase genes could be associated with lesser telomerase activity and, therefore with a shorter leukocyte telomere length was not confirmed in any group of subjects included in our study (Table 4: genotype frequencies of TERT and TERC SNPs in cases and controls).

Our analysis reveals that the relationship between telomere length and cataract was not affected by cardiovascular risk factors such as diabetes, smoking, and hypertension across all groups.

In patients with cataracts, MANOVA indicated no significant $(p>0.05)$ differences in leukocyte telomere length according to the factors hypertension, diabetes, smoking, and age. The $p$-value obtained in the ANOVA test for each of these cardiovascular risk factors was $>0.05$.

However, as age does not follow a parametric distribution, we used the Mann-Whitney $U$ test and a significant effect of age on leukocyte telomere length was then observed $(p<0.05)$.

\section{Discussion}

Human cataractogenesis is characterized by the senescence of lens cells. This senescence is expedited by 
Table 4. Genotype frequencies of TERT and TERC SNPs in cases and controls

\begin{tabular}{|l|l|c|c|c|}
\hline SNP & Genotype & $\begin{array}{c}\text { Cases } \\
\text { n (\%) }\end{array}$ & $\begin{array}{c}\text { Controls } \\
\text { n (\%) }\end{array}$ & p-value \\
\hline TERT & TT & $31(3.4)$ & $26(25.2)$ & 0.7 \\
rs2735940 & TC & $54(52.9)$ & $58(56.3)$ & 0.44 \\
& CC & $17(16.7)$ & $19(18.4)$ & 0.44 \\
& TT & $31(3.4)$ & $26(25.2)$ & \\
& TC + CC & $71(69.9)$ & $77(74.8)$ & \\
& TT + TC & $85(83.3)$ & $84(81.55)$ & \\
\hline TERC & CC & $17(16.7)$ & $19(18.4)$ & \\
rs2293607 & AA & $60(58.8)$ & $69(67.7)$ & 0.38 \\
& AG & $38(37.3)$ & $29(28.2)$ & 0.25 \\
& GG & $4(3.9)$ & $5(4.9)$ & 1 \\
& AA & $60(58.8)$ & $69(67)$ & \\
& AG + GG & $42(41.2)$ & $34(33)$ & \\
& AG + AA & $98(96.1)$ & $98(95.1)$ & \\
& GG & $4(3.9)$ & $5(4.9)$ &
\end{tabular}

SNP: polymorphism; A: adenine; G: guanine; T: thymine; C: cytosine; TERT: telomerase reverse transcriptase; TERC: telomerase RNA component.

oxidative stress and non-ionizing radiation in the form of ultraviolet light that induces DNA damage due to oxygen-derived free radicals. Due to the absence of telomerase activity in the lens, the oxidative attack by phospholipid hydroperoxides present in the aqueous humor and lens cell membrane damage likely produce telomere shortening $1,6,23,24$. Therefore, increased oxidative stress and the lack of reductive detoxification of phospholipid hydroperoxides are the triggering mechanisms of telomere shortening and human cataractogenesis.

Here, we observed that greater lens transparency was related to a longer leukocyte telomere length, as has been reported by other groups ${ }^{6,13,23}$.

To the best of our knowledge, this is the first study to examine leukocyte telomere length in young patients with cataract and to report relatively short lengths for the age range. We observed that younger persons with cataract had shorter telomeres than age-matched controls without cataract. Moreover, this group of patients also showed a shorter telomere length compared to older subjects with cataracts.

We speculate that this finding may reflect premature aging in this population. Accordingly, the onset of cataracts in young adults may serve as an in vivo marker of natural aging and could also warn of other conditions associated withtelomereshorteningandagingsuchasglaucoma, age-related maculardegeneration ${ }^{25}$, cardiovasculardisease, orcancer. Telomerescould bethereforeconsiderednovelbiomarkers of aging and also predictors of the risk of certain age-related degenerative diseases. Thus, telomere length could help monitor the efficiency of prevention or/and strategies aimed at modifying the aging process.
The lens has several real advantages as a marker of aging. For example, using noninvasive, nonhazardous, and quick imaging techniques, we can measure its transparency on a continuous scale. Moreover, the use of a grading system such as the LOCS III offers a reproducible and accurate way to determine lens transparency.

Our results also revealed that the TERT and TERC gene polymorphisms, rs2735940, and rs2293607 were not associated with telomere shortening in any group, including younger people with cataracts. This means that the telomere shortening observed in our study in young people with cataracts was not associated with these SNPs.

Several reports ${ }^{7-11}$ inform a link between short telomere length and cardiovascular risk factors, including hypertension, diabetes, or smoking. We analyzed the relationship between potential confounders (diabetes, hypertension, and tobacco) and leukocyte telomere length. Our study participants were stratified by age, sex, and cardiovascular disease, as shown in Table 1. In patients with cataracts, no relationship emerged in our multivariate analysis between telomere length, age, and cardiovascular risk factors.

This indicates that the telomere shortening in young patients with cataracts observed in our study was not influenced by cardiovascular risk factors or telomerase polymorphisms, meaning that this shortening could be directly associated with cataracts. Future longitudinal studies are needed to confirm our hypothesis and strengthen the idea that early cataracts could indicate premature aging and the possible presence of age-related disease.

Several limitations should be considered to interpret our results. Telomere length in peripheral leukocytes may not reflect telomere length alterations in lens cells, although several studies have shown their good correlation ${ }^{12,13,24}$. Furthermore, as we wanted to examine a cohort of subjects representative of the general population, women were not excluded from the study. However, it is well known that adult women have a longer leukocyte telomere length than $\operatorname{men}^{26}$, although, at birth, telomere length is equivalent in boys and girls ${ }^{12,27}$. Another limitation is that cigarette smoking accelerates telomere shortening and this has been linked to multiple negative health outcomes over a person's lifetime ${ }^{28}$. Some studies have found a dose-response relationship between cumulative lifetime exposure to cigarette smoking and telomere length in adults ${ }^{29}$. Nevertheless, to avoid these confounding factors, we balanced out smokers in all the groups included in our study.

Finally, other factors such as shelterin complex ${ }^{30,31}$ should be considered. Telomeres consist of tandem repeats of a DNA sequence connected to six-protein 
components known as shelterins ${ }^{30}$, being Telomere Repeat binding Factor 1 (TRF1) and Adrenocortical Dysplasia Protein Homolog (TPP1) the most relevant proteins in mammals. Shelterin proteins are specialized in protecting telomeres from DNA repair mechanisms and in regulating telomerase activity. Accordingly, the suppression of TRF1 and TPP1 results in the development of age-related and degenerative pathologies such as dyskeratosis congenita, aplastic anemia, and idiopathic pulmonary fibrosis in young mice. These diseases are associated with short/ dysfunctional telomeres and a characteristic failure in the regenerative ability of tissues ${ }^{31}$. Consequently, there are other complexes such as shelterin, in addition to telomerase polymorphisms, that act on this enzyme conditioning telomere length, and therefore, they may participate in the appearance of age-related diseases such as cataracts.

While it is difficult to recruit young patients with cataracts, the link observed here between a short telomere length and premature cataract requires confirmation in larger patient series.

\section{Conclusions}

We report for the first time that younger people with cataract show a shorter leukocyte telomere length compared to subjects without cataract and that this relationship is not affected by cardiovascular risk factors or telomerase polymorphisms. If this link is confirmed in larger patient series, we hypothesize that the early development of cataracts and short telomere length could be a marker of premature aging.

\section{Funding}

Health research program of the "Instituto de Carlos III" (Pl13/01741) co-financed with FEDER funds. "The funding organization had no role in the design or conduct of this research."

\section{Conflicts of interest}

The authors report no conflicts of interest.

\section{Ethical disclosures}

Protection of human and animal subjects. The authors declare that the procedures followed were in accordance with the regulations of the relevant clinical research ethics committee and with those of the Code of Ethics of the World Medical Association (Declaration of Helsinki).
Confidentiality of data. The authors declare that they have followed the protocols of their work center on the publication of patient data.

Right to privacy and informed consent. The authors have obtained the written informed consent of the patients or subjects mentioned in the article. The corresponding author is in possession of this document.

\section{References}

1. Von Zglinicki T. Will your telomeres tell your futures? BMJ. 2012;344:e1727.

2. De Rooij SR, Roseboom TJ. The developmental origins of ageing: study protocol for the Dutch famine birth cohort study on ageing. BMJ Open. 2013;3:e003167.

3. Calado RT, Young NS. Telomere diseases. N Engl J Med. 2009;361:235365.

4. Njajou OT, Blackburn EH, Pawlikowska L, Mangino M, Damcott CM, Kwok PY, et al. A common variant in the telomerase RNA component is associated with short telomere length. PLoS One. 2010;5:e13048.

5. Matsubara Y, Murata M, Yoshida T, Watanabe K, Saito I, Miyaki K, et al. Telomere length of normal leukocytes is affected by a functional polymorphism of hTERT. Biochem Biophys Res Commun. 2006;341:128-31.

6. Von Zglinicki T, Martin-Ruiz CM. Telomeres as biomarkers for ageing and age-related disease. Curr Mol Med. 2005;5:197-203.

7. Zee RY, Castonguay AJ, Barton NS, Germer S, Martin M. Mean leukocyte telomere length shortening and Type 2 diabetes mellitus: a case-control study. Transl Res. 2010;155:166-9.

8. Testa R, Olivieri F, Sirolla C, Spazzafumo L, Rippo MR, Marra M, et al. Leukocyte telomere length is associated with complications of Type 2 diabetes mellitus. Diabetic Med. 2011;28:1388-94.

9. Babizhayev MA, Yegorov YE. Smoking and health: association between telomere length and factors impacting on human disease, quality of life and life span in a large population-based cohort under the effect of smoking duration. Fundam Clin Pharmacol. 2011;25:425-42.

10. Demissie S, Levy D, Benjamin EJ, Cupples LA, Gardner JP, Herbert A, et al. Insulin resistance, oxidative stress, hypertension, and leukocyte telomere length in men from the Framingham heart study. Aging Cell. 2006;5:325-30.

11. Fitzpatrick AL, Kronmal RA, Gardner JP, Psaty BM, Jenny NS, Tracy RP et al. Leukocyte telomere length and cardiovascular disease in the cardiovascular health study. Am J Epidemiol. 2007;165:14-21.

12. Aviv A, Valdes AM, Spector TD. Human telomere biology: pitfalls of moving from the laboratory to epidemiology. Int $\mathrm{J}$ Epidemiol. 2006;35:1424-9.

13. Sanders JL, lannaccone A, Boudreau RM, Conley YP, Opresko PL, Hsueh WC, et al. The association of cataract with leukocyte telomere length in older adults: defining a new marker of aging. J Gerontol A Biol Sci Med Sci. 2011;66:639-45.

14. Dollfus H, Porto P, Caussade P, Speeg-Schatz C, Sahel J, Grosshans E, et al. Ocular manifestations in the inherited DNA repair disorders. Surv Ophthalmol. 2003;48:107-22.

15. Kipling D, Davis T, Ostler ET, Faragher RG. What can progeroid syndrome tell us about human aging? Science. 2004;305:1426-31.

16. Gomez-Sanchez JC, Delgado-Esteban M, Sobrino T, Sobrino T, de la Ossa NP, Reverte S, et al. The human Tp53 Arg72Pro polymorphism explains different functional prognosis in stroke. J Exp Med. 2011;208:429-37

17. Gil ME, Coetzer TL. Real-time quantitative PCR of telomere length. Mol Biotechnol. 2004;27:169-72.

18. Cawthon RM. Telomere measurement by quantitative PCR. Nucleic Acids Res. 2002;30:e47.

19. Perez-Rivera JA, Pabon-Osuna P, Cieza-Borrella C, Herrero FM, Gonzalez-Porras JR, González R. Prognostic value of telomere length in acute coronary syndrome. Mech Ageing Dev. 2012;133:695-7.

20. Perez-Rivera JA, Pabon-Osuna P, Cieza-Borrella C, Duran-Bobin O, Martin-Herrero F, Gonzalez-Porras JR, et al. Effect of telomere length on prognosis in men with acute coronary syndrome. Am J Cardiol. 2014; $113: 418-21$.

21. Martinez-Delgado B, Yanowsky K, Inglada-Perez L, Domingo S, Urioste $\mathrm{M}$, Osorio A, et al. Genetic anticipation is associated with telomere shortening in hereditary breast cancer. PLoS Genet. 2011;7:e1002182.

22. Killick E, Tymrakiewicz M, Cieza-Borrella C, Smith P, Thompson DJ, Pooley KA, et al. Telomere length shows no association with BRCA1 and BRCA2 mutation status. PLoS One. 2014;9:e86659.

23. Berthoud VM, Beyer EC. Oxidative stress, lens gap junctions, and cataracts. Antioxid Redox Signal. 2009;11:339-53. 
24. Babizhayev MA, Vishnyakova KS, Yegorov YE. Telomere-dependent senescent phenotype of lens epithelial cells as a biological marker of aging and cataractogenesis: the role of oxidative stress intensity and specific mechanism of phospholipid hydroperoxide toxicity in lens and aqueous. Fundam Clin Pharmacol. 2010;25:139-62.

25. Weng X, Zhang H, Kan M, Ye J, Liu F, Wang T, et al. Leukocyte telomere length is associated with advanced age-related macular degeneration in the Han Chinese population. Exp Gerontol. 2015;69:36-40.

26. Benetos A, Okuda K, Lajemi M, Kimura M, Thomas F, Skurnick J, et al. Telomere length as an indicator of biological aging: the gender effect and relation with pulse pressure and pulse wave velocity. Hypertension. 2001;37:381-5.

27. Okuda K, Bardeguez A, Garner JP, Rodriguez P, Ganesh V, Kimura M, et al. Telomere length in the newborn. Pediatr Res. 2002;52:377-81.
28. Weischer M, Bojesen SE, Nordestgaard BG. Telomere shorting unrelated to smoking, body, weight, physical activity, and alcohol intake: 4,576 general population individuals with repeat measurements 10 years apart. Plos Genet. 2014;10:e1004191.

29. Theall KP, Mckasson S, Mabile E, Dunaway LF, Drury SS. Early hits and long-term consequences: tracking the lasting impact of prenatal smoke exposure on telomere length in children. Am $\mathrm{J}$ Public Heatlh. 2013;103:133-5.

30. García-Beccaria M, Martínez P, Flores JM, Blasco MA. In vivo role of checkpoint kinase 2 in signaling telomere dysfunction. Aging Cell. 2014;13:810-6.

31. Donate LE, Blasco MA. Telomeres in cáncer and ageing. Phil Trans R Soc B. $2011 ; 366: 76-84$. 